\title{
Occupational Stress and Coping among Portuguese military Police Officers
}

\section{Estrés ocupacional y afrontamiento en oficiales de la policía militar portuguesa Stress Ocupacional e Afrontamento em Oficiais da Polícia militar Portuguesa}

\author{
A. Rui Gomes, ${ }^{*}$ Jorge M. P. Afonso* \\ University of Minho, School of Psychology, Portugal.
}

Doi: dx.doi.org/10.12804/ap134.1.2016.04

\section{Abstract}

This study describes the professional experience of military police officers from the Portuguese Republican National Guard $(N=95)$. We focused on the main sources and consequences of stress and the coping strategies used to deal with stress. The evaluation protocol included one closed-ended question and four open-ended questions. Data analysis of meaningful text segments was conceptually based and data categorization followed deductive content analysis. Results allowed the identification of 483 meaning units. Factors intrinsic to the job and the relationships at work were the main stressors referred by participants. The consequences of stressors were evident at an individual level, affecting family, psychological, and physical/health domains. The coping strategies used to deal with the main source of stress in the professional career were focused on problem solving (e.g., active confrontation) and emotional regulation (e.g., situation acceptance). Practical implications and future avenues of research with these professionals are discussed.

Key words: police; occupational stress; sources of stress; coping.

\section{Resumen}

Este estudio analiza la experiencia profesional de agentes de la policía militar de la Guarda Nacional Republicana portuguesa $(N=95)$. Se centró en las principales fuentes y consecuencias del estrés, así como en las estrategias de afrontamiento. El protocolo de evaluación incluyó una pregunta cerrada y cuatro abiertas. Se realizó una categorización de datos atendiendo a un análisis de contenido deductivo. Las respuestas permitieron establecer 483 unidades de significado, a partir de las cuales se identificaron las principales quejas, relacionadas con factores intrínsecos al trabajo y a las relaciones interpersonales. Las consecuencias de estos problemas fueron evidentes en el plano individual (psicológicas y de salud física) y también afectaban a la familia. Las habilidades utilizadas para hacer frente a las principales fuentes de estrés estaban centradas en la resolución de problemas y el control emocional. Se discuten las implicaciones prácticas y las futuras vías de investigación con estos profesionales.

Palabras clave: policía; estrés ocupacional; fuentes de estrés; afrontamiento.

\footnotetext{
* The correspondence to this article must be send to A. Rui Gomes, Universidade do Minho, Escola de Psicologia, Campus de Gualtar, 4710-057 Braga. Portugal. Telf.+253604232; Fax:+253604221. E-mail: rgomes@psi.uminho.pt
}

How to cite this article: Gomes, A. R. \& Afonso, J. M. P. (2016). Occupational stress and coping among Portuguese military police officers. Avances en Psicología Latinoamericana, 34(1), 47-65. doi: dx.doi.org/10.12804/apl34.1.2016.04 


\section{Resumo}

Este estudo analisa a experiência profissional de agentes da polícia militar da Guarda Nacional Republicana Portuguesa $(N=95)$. Centramo-nos nas principais fontes e consequências do stress assim como nas estratégias de afrontamento. O protocolo de avaliação incluiu uma pergunta fechada e quatro abertas. Realizou-se uma categorização de dados atendendo a uma análise de conteúdo dedutivo. As respostas permitiram a identificação de 483 unidades de significado, a partir das quais se identificaram as principais queixas. Estas estavam relacionadas com fatores intrínsecos ao trabalho e relações interpessoais. As consequências destes problemas foram evidentes no nível individual (psicológicas e saúde física) afetando também à família. As habilidades utilizadas para fazer frente às principais fontes de stress estavam centradas na resolução de problemas e o controle emocional. Discutem-se as implicações práticas e as futuras vias de pesquisa com estes profissionais.

Palavras-chave: polícia; stress ocupacional; fontes de stress; afrontamento.

The job of police officer is one of the most stressful occupations in the world (Campbell \& Nobel, 2009). The nature of the tasks they must do justifies this classification because beyond all the most common problems associated with other occupations (for example: working by shifts, excess of working hours, lack of communication, conflicts in the relationships with colleagues and superiors, etc.), these individuals have to face specific pressures common to their own profession: to put their life at risk while they protect themselves and the lives of others.

The consequences of this specificity have been reported in the literature, being described potential problems in terms of psychological well-being (Brough, 2004), posttraumatic stress symptoms (Violanti et al., 2006), physical health (Abdollahi, 2002), burnout (Burke \& Mikkelsen, 2006), family relations (Alexander \& Walker, 1996), and professional performance (LeBlanc, Regehr, Jelley, \& Barath, 2008).

Knowing the importance of this profession, and the potential social and economic costs of low performance, it makes sense that studies continue to analyse the complexities underlying the police officer activity (De Boer, Bakker, Syroit, \& Schaufeli, 2002; Shaufeli \& Enzmann, 1998). In this way, one of the most important steps in handling occupational stress is to identify the factors that may be related to distress (Dewe, O'Driscoll, \& Cooper, 2010; Payne \& Cooper, 2004) and the way individuals deal with stressors at work. Considering these aspects, this study adopted a qualitative approach in order to analyse the relationship between occupational stress (e.g., work factors that can cause strain to the individual), consequences of stress (e.g., individual and organizational problems due exposition to occupational stress), and coping strategies (e.g., efforts made by the individual in order to deal with occupational stress).

As referred by Campbell and Nobel (2009), there is now a substantial knowledge about the causes and consequences of occupational stress on workers and work performance, but this information follow a "context-free" orientation that is not integrated into a cohesive whole. So it becomes crucial to determine the contextual diversity in the workplace, particularly in the professions where it is more evident the risks for occupational stress, as is the case of military and police forces. This study was done according this idea, analysing three main aspects: (1) the levels of stress in the professional activity, (2) the usual sources of stress in the workplace and their consequences in the participants' well-being, and (3) the main sources of stress throughout the professional career and the coping strategies used to deal with these problems.

Regarding the first goal, it was analysed the global level of stress in this professional activity, offering some comparison with other studies done 
with police officers. We should mention that the participants of this study have some characteristics that are unique in the context of public security. In fact, they are part of the Portuguese Republican National Guard, which is composed by individuals with military training being organized in a special core of troops with the mission to maintain the public order and the security of people and goods. For example, one duty that characterizes this security force, and that tends to be different from others police corporations, is their support in implementing the policy of national defense. Because of that, during this study we will make reference to these professionals as "military police officers."

In what concerns the second goal, we analysed the usual sources of stress and their consequences in the personal well-being of military police officers. For that, we adopt a qualitative descriptive analysis based on Cooper, Dewe, and O'Driscoll (2001) classification of job stressors at work that allowed us to characterize the work of military police officers and contrast their sources of stress with other security forces (e.g., Brown \& Campbe11, 1994; Burke \& Mikkelsen, 2006; Toch, 2002). Again, we should mention the scarce of qualitative research done on this subject. In fact, there are not many studies (particularly in Portugal) focused on the analysis of the characteristics and demands of this occupation and the potential damages on the military police officers.

The final goal of the study was to analyse the main sources of stress in the professional career and the coping strategies used to deal with these stressors, using again a qualitative approach of data analysis. More specifically, we observed the relationship between the main source of stress and the coping strategies used to deal with the strains of the job. This analysis followed Lazarus (1991, 2000) suggestions that claims the need to study in a single conceptual framework the stress, the emotions and the coping responses, because the stress experience results from the transaction between a particular external condition and a single individual. So the main interest should be placed on the psychological processes that occur in this transaction (Lazarus \& Folkman, 1984), as is the case of coping processes that results from a stressful situation. As stated by Lazarus (1999), the frequent separation of these concepts in research is only justified by easiness in data analysis, turning it difficult to understand the overall process of human adaptation to stress. As reinforced by Biggam, Power, and MacDonald (1997a) there are not many studies about this subject in police officers being difficult to understand the way they respond to the specific sources of stress.

Being so, by adopting a qualitative methodology in this study we tried to understand the specific factors of stress that military police officers face in their job, instead of using a quantitative methodology of sources of stress that could not represent the real demands of this activity. And most important, the qualitative approach allowed to understand the relationship between the usual sources of stress and the consequences in the personal well-being of military police officers, and also allowed to understand of the relationship between the main source of stress and the coping responses, being analysed the stress experiences, the consequences of stress, and the coping strategies used to deal with pressures of work. In sum, this study tried to understand the work experience of a sample of military police officers by analysing in a integrative way the usual and main sources of stress, the consequences of stress, and the coping responses used to deal with stress. This allowed us to respond to one of the major challenges in the study of occupational stress related to the need of integrating in a single conceptual framework the analysis of stress, emotions, and coping strategies (Gomes, 2014; Lazarus, 2000).

Taking into consideration these ideas, we present below the conceptual proposals adopted to treat and interpret the data obtained in this study, focusing in the stress and coping domains. 


\section{Conceptual Background Adopted in Data Analysis}

In what concerns the analysis of the sources of stress, we adopted a common classification of job stressors at work that have differentiated six primary work-related stressors: (1) factors intrinsic to the job, (2) roles in the organization, (3) relationships at work, (4) career development issues, (5) organizational structure and climate, and (6) home-work interface (Cooper et al., 2001). The first five categories are related to stressors within the workplace environment, whereas the sixth focuses on the interplay between the job and the personal life.

Concerning the intrinsic job characteristics, these stressors are associated with the performance of specific tasks that are part of an individual's job as well as the work environment and the work-scheduling factors. Some examples of these categories are poor working conditions (ex.: noise, vibration, and temperature, etc.), work shifts, excessive working hours, travel, personal risks and dangers, new technology, work overload and work under load.

In the organizational roles (second domain of stress), it is included the behaviors and demands that are related to the job an individual performs. In this case, there are four sources of stress: (1) role ambiguity: lack of clear understanding of work goals, co-workers' expectations, and the responsibilities of the job; (2) role conflict: tension between job demands due to the perception that the professional is doing things that doesn't want to do or is doing things not considered to be part of the job; (3) responsibility: stress arises when the professional feels tension because of his/her responsibility for things (ex.: budgets or equipment), or the responsibility for people (ex.: the necessity of interacting with others or attending meetings); and (4) role overload: number of different roles a person has to fulfil.

The third area of stress refers to work relationships. In this case, stress is related to the relationship with chiefs/managers (e.g., low consideration, mu- tual trust and respect, etc.), with subordinates (e.g., ability to delegate, autocratic and authoritarian leadership styles, orientation to the development of good relationships, etc.), and the relationships with colleagues (e.g., competition, conflicts and lack of social support between the group members etc.).

Career development represents the fourth source of stress. Some examples of these potential problems are the lack of job security, low payment, perceived under or over promotion, fear of job loss, obsolescence, retirement, being evaluated and appraised by the superiors, etc.

Organizational factors (fifth domain) produce psychological strain due to the culture and management style adopted within an organization. Some examples are the hierarchical and bureaucratic organizational structures that discourage the participation of employees in decision making, the excessive formalization of work and the office and organization politics.

Finally, home-work interface describes the problems in the family because of the job (ex.: having to do extra work at home, lack of time to be with their children, etc.) and the problems at work because of personal problems (ex.: having a disease, facing a divorce, etc.).

These six areas can produce distress in the worker causing individual (ex.: depressive mood, irritability, etc.) and organizational symptoms (ex.: absenteeism, turnover, difficult industrial relations, and poor quality control) that can have as final consequence the development of diseases (ex.: coronary heart disease, mental illness) and the existence of prolonged strikes, frequent and severe accidents, and poor performance (Cooper et al., 2001).

For the evaluation of the coping strategies used by the military police officers, we token into consideration the coding system proposed by Carver, Scheier, and Weintraub (1989) and Lazarus and Folkman (1984) conceptual model. According to these last authors, stress can be understood in three temporal processes. First, the primary appraisal 
is the process of perceiving a threat to oneself. Second, it emerges the secondary appraisal that corresponds to the process of bringing to mind a possible response to the threat. Third, coping is the process of executing that response, which can be organized in two types. The first one is problem-focused coping, which is oriented to problem solving and doing something to alter the source of stress. The second one is emotion-focused coping that refers to the efforts of the person to reduce or manage the emotional distress that is associated with (or cued by) the situation (Folkman, 2008). Lazarus and Folkman (1984) proposed that emotion-focused coping could be more active, when the individual tries, for example, venting one's emotional distress or cognitively reframing a stressor's impact, or could be avoidant/passive, when the person uses denial or self-distraction to avoid the source of distress (without engaging in problem-focused behavior). This division is important because there is evidence that avoidant emotional coping leads to mental health problems (Coyne \& Racioppo, 2000).

Although most stressors can originate both kinds of coping responses, it is accepted that problem-focused coping is more prevalent when the person has some control in the stressful situation and feels that there is something useful to do to alter or resolve the problem. By the contrary, when the person perceives little control in the situation and feels there is nothing to do to alter the source of stress, then he or she may demonstrate a tendency to manage the distress and the negative emotions that result from the situation (Folkman \& Lazarus, 1980).

There are various methodologies to access the coping responses (see, for example, Folkman \& Lazarus, 1988). In this study, we adopt the categorization of Carver et al. (1989) in the development of the COPE inventory. The instrument is based on the Lazarus Model (Lazarus \& Folkman, 1984) and on the Model of Behavioural Self-Regulation (Scheier \& Carver, 1988). The COPE inventory incorporates fourteen conceptually different scales: (1) active coping: process of taking active steps to remove or circumvent the stressor or to ameliorate its effects; (2) planning: involves coming up with action strategies, thinking about what steps to take and how to best handle the problem; (3) suppress competitive activities: means putting other projects aside, trying to avoid becoming distracted by other events, and even putting other things aside in order to deal with the stressor; (4) restraint coping: waiting until an appropriate opportunity to act presents itself, holding oneself back, and not acting prematurely; (5) seeking social support for instrumental reasons: asking advice, assistance or information in order to manage or resolve the situation; (6) seeking social support for emotional reasons: getting moral support, sympathy, or understanding of others in order to help managing the distress; (7) focusing on and venting of emotions: tendency to focus on the aspects that distress or upset the individual and to ventilate those feelings; (8) behavioral disengagement: tendency to reduce the efforts to deal with the stressor, giving up of the goals with which the stressor is interfering; (9) mental disengagement: assuming a wide variety of activities that serve to distract the person from thinking about the behavioral dimension or goal with which the stressor is interfering; (10) positive reinterpretation and growth: tendency to attribute a new and different meaning to the distressing emotions rather than dealing with the stressor per se; (11) denial: refusal to believe that the stressor exists or try to act as though the stressor is not real; (12) acceptance: recognizing the reality of a stressful situation, assuming that nothing could be done; (13) turning to religion: tendency to turn to religion in times of stress; and (14) alcohol-drug disengagement: consume of alcohol and drugs to feel better in the stressful situation (Carver et al., 1989).

The conjunction of these models and principles were the basis for this study. More specifically, military police officers were asked about their own professional experience, giving their answers 
by hand in an evaluation protocol designed for this purpose. This allowed us a more detailed understanding of their opinions, expectations, and feelings, avoiding the usual constrains of using Likert scales, where the dimensions and categories of information are already defined. The treatment of data collected from the military police officers followed structural analysis (Tesch, 1990) because all the categories of information were integrated in the conceptual models and principles described before regarding occupational stress, consequences of stress, and coping strategies.

In this sense, three specific goals were formulated for this study:

1. Evaluate the frequency of global stress in the professional practice.

2. Analyse the usual sources of stress in the work place and the consequences in the participants.

3. Analyse the main sources of stress throughout the professional career and the coping strategies used to deal with these problems.

\section{Method}

\section{Participants}

The sample for this study was a convenience one including 95 military police officers from the Portuguese Republican National Guard, who were working at different locations in the north of Portugal (90 males: $94.7 \%$, and 5 females: $5.3 \%$ ). The age varied between 22 and 54 years $(M=37.4 ; S D$ $=10.3$ ). In terms of marital status, 30 participants were single (31.9\%), 60 were married $(63.8 \%)$, and 4 were divorced (4.3\%). All participants had received elementary education that corresponds to the request legal level of education in Portugal. From their hierarchical position, 62 participants were soldiers $(68.1 \%), 20$ were corporals, $(22 \%)$, and 9 were sergeants $(9.9 \%)$. The years of practice ranged between 1 and 27 years $(M=8.4 ; S D=8.4)$. The number of hours worked per week presented a great amplitude of time, from a minimum of 25 hours until a maximum of 70 hours $(M=48 ; S D=7.1)$.

\section{Measures}

The evaluation protocol included one question in "Likert" format and four open-ended questions about the professional experience of military police officers.

Global Level of Stress. Based on the original work of Kyriacou (2000), it was evaluated perception of military police officers about the global level of stress they feel in the professional activity, using a "Likert" scale of five points, from zero ("No stress") to four ("High stress level"). This scale has the advantage of using only one item to evaluate work stress not requiring too much time to be responded, which was essential because the second part of the evaluation protocol, described below, needed more time to be answered by the participants.

Military Professional Experience. This section of the evaluation protocol was constituted by four open-ended questions with the intent to evaluate: (1) the usual sources of stress and pressure in the profession, (2) the consequences of the usual sources of stress, (3) the main source of stress and pressure in the whole professional career, and (4) the coping strategies used to deal with the main source of stress. The answers to these questions were written by hand on the evaluation protocol. The methodology used for the construction of these questions followed Folkman, Lazarus, Dunkel-Schetter, De Longis, and Gruen (1986) instructions that emphasized the need of more specific measures into stress research related to working environments. Being so, the questions were presented in a logical sequence, starting with the evaluation of general sources of stress, followed by the consequences of these problems (questions one and two). Questions three and four intended to identify main 
"critical events" (Alexander \& Klein, 2001; Carver et al., 1989; Folkman \& Lazarus, 1988; Vanheule, Declercq, Meganck, \& Desmet, 2008), questioning the participants about the situation that has caused the greatest level of stress in their careers and the way they tried to cope with these events. This division between "usual stressful sources" and "main source of stress" is based on research guidelines in occupational stress that accentuate the need of measure both the experiences of trauma and frequent minor stressors (daily hassles), in order to obtain a better understanding of psychological health and well-being at work (Brough, 2002; Hart \& Cotton, 2003; Kop, Euwema, \& Schaufeli, 1999).

\section{Procedure}

The study started with an authorization request sent to the Territorial Command Group of Braga (North of Portugal), explaining the main objectives of the research and the procedures used to collect, treat, and divulge the results. As we received the Territorial Command Group's consent, we initiated our fieldwork by contacting the Post Commanders of each workplace. Once the authorization for applying and collecting the evaluation protocol was guaranteed, one member of the research group went to each work place. Then, a private place to collect the data was defined, and only the participants could go inside that place. The questionnaire was filled out on days of instruction in order to not interfere with the routine of their professional activity. The evaluation protocol included a presentation letter containing information about the goals and implications of the present study, assuring that their participation was voluntary and confidential. The military police officers were free to decide whether they wanted to take part of the study and it has not offered any financial incentive or material prize for the participation.

The questionnaire application was completed individually and collected at one time, taking about 15 to 30 minutes to complete. To guaranty the confidentiality and the anonymity of the collected data, we handed out an envelope to all the participants where they could insert their questionnaire when they had finished filling it out. Only the researchers of this study where allowed to open the envelopes, guarantying the data's confidentiality.

The evaluation protocol was distributed to $95 \mathrm{mi}-$ litary police officers, having been received and considered valid for data analysis all the questionnaires. This sample corresponds to $37 \%$ of the military police officers that were working in the evaluated Post Commanders and represents $15 \%$ of the individuals that were working in the Territorial Command of the Portuguese Republican National Guard.

\section{Data Analysis}

Because the stress and coping models were conceptually defined, data was analysed using deductive content analysis (Patton, 1990). The units of analysis were the written descriptions given in the four open-ended questions. For each question, responses were organized into categories according to their nature and when necessary, new categories and subcategories were developed to represent the specificity of the data. This procedure allowed a meaning unit with similar connotations to be more precisely clarified and to achieve what Weber (1985) describes as semantic validity, because the categories were formulated on a conceptual basis. This method differs from inductive content analysis because in this case, the investigator "allows" the participants' responses to emerge, creating their own themes, rather than being assigned into predetermined categories, driven by the existing conceptual framework under study. Although one of the limitations of deductive content analysis is the categorization of the data into predefined domains, this procedure can facilitate a coherent theoretical understanding of complex psychological and behavioral processes (Lincoln \& Guba, 1985). On the other hand, the classification according to preconceived constructs can also reduce the probability 
of the investigator's system of analysis influencing the participants' responses (Patton, 1990).

Given the large amount of qualitative data, we used the method cut-up-and-put-infolders approach (Bodgan \& Biklen, 2006), being divided the text into meaning units and then giving a tag to the text segment. Being so, all the meaning units and subsequent tags were numbered, being the process finalized when all the meaning units had a specific tag and a representative category. The coding process of the answers was done taking into consideration the theoretical background referred earlier. After concluding this task, we asked for the cooperation of two psychology professionals, who had an interest in occupational stress. The tasks of these professionals included the analysis of the coding system, acting as "the devil's advocate" by questioning the proposed categorization, and indicating eventual modifications.

The methodology used in the meeting with the two psychology experts was the following: (1) before the group encounter, we distributed a technical report with information about the research so they could become familiarized with the conceptual aspects followed in the data analysis (e.g., goals, procedure, methodology, conceptual models, and code grills that served to analyse the data); and (2) during the two meetings with the experts we asked each one to read all the meaning units and evaluate the categorization proposed by us, and only afterwards we began the group discussion. This option aimed to reduce the influence over the elements of the jury, because each one of them had to make a preliminary judgement of the codification before starting the group reflection.

Modifications were made only when there was consensus between both parts. These consultations took place during two meetings (in the morning and in the afternoon of the same day), in a total of 5.30 hours of work, and the following modifications were made: (1) change of the code of thirteen meaning units for other categories, (2) the division of six meaning units into more segments, (3) elimination of two meaning units (passing to the category "non-coded"), and (4) modification of the designation of a subcategory. Based on indications provided by Rourke, Anderson, Garrison, and Archer (2001) and the Holsti's (1969) Coefficient of Reliability (e.g., C. R. $=2 \mathrm{~m} / \mathrm{n} 1+\mathrm{n} 2$, where $m$ corresponds to the number of coding decisions upon which the two coders agree, and $n 1$ and $n 2$ corresponds to the number of coding decisions made by coders 1 and 2, respectively), we calculated the inter-rater reliability, being found an very acceptable level of $95.6 \%$, above the minimum level of $80 \%$ established as a standard indicator (see Riffe, Lacy, \& Fico, 1998).

\section{Results}

Based on the global level of stress that the military police officers felt in the professional practice, it should be underlined that $54 \%$ revealed significant scores of stress (the sum of the values three and four of Likert the scale) and the other $46 \%$ demonstrated low to moderate values (sum of the values one and two). None of the participants assumed the value "no stress" on the measurement scale.

The analysis of the four open-ended questions allowed the identification of 515 meaning units. However, due to the difficulty in obtaining a valid and unequivocal comprehension of the given answers, 32 units of information were eliminated $(5.2 \%)$, leaving the final protocol with a representation of 483 codes, organized in the following way: 182 in the usual sources of stress $(37.7 \%), 153$ in the consequences of usual stress (31.7\%), 75 main sources of stress in the whole career $(15.5 \%)$, and 73 in the coping strategies to deal with the main sources of stress $(15.1 \%)$. For a better understanding of all the information described in those four questions, table 1 gives examples of each meaning unit for all categories. 
Table 1

Meaning Unit Examples for the Established Categories

\begin{tabular}{|c|c|}
\hline \multicolumn{2}{|c|}{ Sources of stress } \\
\hline Intrinsic to the job & Example \\
\hline $\begin{array}{l}\text { Risks and dangers to the } \\
\text { military and/or to other } \\
\text { persons }\end{array}$ & $\begin{array}{l}\text { I had to point my gun at a } \\
\text { suspect who had stolen a car } \\
\text { with a woman onboard and was } \\
\text { threatening her with a rifle }\end{array}$ \\
\hline $\begin{array}{l}\text { Work schedules, shift } \\
\text { work, and working in the } \\
\text { weekend }\end{array}$ & $\begin{array}{l}\text { Only having one weekend free } \\
\text { each seven weeks of work, and } \\
\text { sometimes this weekend off is } \\
\text { delayed }\end{array}$ \\
\hline $\begin{array}{l}\text { Lack of resources and } \\
\text { poor working conditions }\end{array}$ & $\begin{array}{l}\text { Lack of personal and material } \\
\text { resources to offer an effective } \\
\text { response }\end{array}$ \\
\hline Excess of working hours & $\begin{array}{l}\text { Due to accidents with injured } \\
\text { individuals, deaths, arrests and } \\
\text { detentions at the end of an offi- } \\
\text { cers` shift, we have to continue } \\
\text { the work schedule }\end{array}$ \\
\hline Work overload & $\begin{array}{l}\text { Having to do our tasks under } \\
\text { pressure due to a great amount } \\
\text { of work }\end{array}$ \\
\hline \multicolumn{2}{|c|}{ Relationships at work } \\
\hline $\begin{array}{l}\text { Relationship with the } \\
\text { commands/superior } \\
\text { officer }\end{array}$ & $\begin{array}{l}\text { The way the commands treat the } \\
\text { military police officers with au- } \\
\text { thority, contempt and disrespect }\end{array}$ \\
\hline $\begin{array}{l}\text { Relationship with co- } \\
\text { lleagues }\end{array}$ & $\begin{array}{l}\text { Bad relationship with the co- } \\
\text { lleagues of the work place }\end{array}$ \\
\hline $\begin{array}{l}\text { Relationship with citi- } \\
\text { zens and community }\end{array}$ & $\begin{array}{l}\text { An increase of the pressure and } \\
\text { demands by the citizens }\end{array}$ \\
\hline
\end{tabular}

\begin{tabular}{ll}
\hline Roles in the organization \\
\hline $\begin{array}{l}\text { Responsibility and func- } \\
\text { tions }\end{array}$ & $\begin{array}{l}\text { Being too much time "behind } \\
\text { a desk" due to the need to do } \\
\text { service to the public } \\
\text { Carry out tasks that do not have } \\
\text { anything to do with my quali- } \\
\text { fications }\end{array}$ \\
Role conflict & $\begin{array}{l}\text { When I was transferred to a new } \\
\text { working place, and I didn't knew } \\
\text { what to do nor where to start }\end{array}$ \\
Role ambiguity & Career development \\
\hline Haven't been promoted to the \\
next position
\end{tabular}

Doing prevention service at prison establishments during 30 straight days without extra retribution

Organiz. structure/climate

\begin{tabular}{ll}
\hline $\begin{array}{l}\text { Bureaucracy, discipline } \\
\text { procedures, and legal } \\
\text { aspects }\end{array}$ & $\begin{array}{l}\text { An accident occurred and the } \\
\text { lack of coordination between } \\
\text { the involved police forces was } \\
\text { evident, due to the many bu- } \\
\text { reaucratic processes }\end{array}$ \\
$\begin{array}{l}\text { Lack of instruction and } \\
\text { training }\end{array}$ & $\begin{array}{l}\text { Lack of permanent technical } \\
\text { information and training }\end{array}$ \\
\hline Home-work interface & \multicolumn{1}{c}{ Example } \\
\hline Working problems & $\begin{array}{l}\text { Conflicts with my family due to } \\
\text { the excessive working hours }\end{array}$ \\
Personal problems & $\begin{array}{l}\text { Having health problems during } \\
\text { several years }\end{array}$
\end{tabular}

Consequences of the usual stress

\begin{tabular}{ll}
\hline \multicolumn{1}{c}{ Individual symptoms } & \multicolumn{1}{c}{ Example } \\
\hline $\begin{array}{l}\text { Problems with signifi- } \\
\text { cant others (e.g., family) }\end{array}$ & $\begin{array}{l}\text { There are many arguments } \\
\text { between my family and me, } \\
\text { leading to relationship ruptures }\end{array}$ \\
Psychological problems & $\begin{array}{l}\text { Psychological speaking, I'm } \\
\text { feeling tired and some apathy }\end{array}$ \\
$\begin{array}{l}\text { Physical and health } \\
\text { problems }\end{array}$ & $\begin{array}{l}\text { I'm physically tired and I have } \\
\text { headaches }\end{array}$ \\
\hline
\end{tabular}

Organizational symptoms

Reduced work performance and efficiency

At a professional level, I feel a performance decrease

Poor relationships at I have more conflicts and prowork blems with my colleagues

Low commitment I feel a disinterest for the mission

Coping strategies to deal with the main sources of stress

\begin{tabular}{ll}
\hline & \multicolumn{1}{c}{ Example } \\
\hline Active coping & $\begin{array}{l}\text { I face the problems and I try to } \\
\text { find out a solution }\end{array}$ \\
\hline $\begin{array}{l}\text { Social support (instru- } \\
\text { mental) }\end{array}$ & $\begin{array}{l}\text { I had to receive psychological } \\
\text { help during three months }\end{array}$ \\
\hline & $\begin{array}{l}\text { I think about what I can do to } \\
\text { obtain a better control over a } \\
\text { specific situation }\end{array}$ \\
\hline
\end{tabular}




\begin{tabular}{|c|c|}
\hline Restraint coping & $\begin{array}{l}\text { [before I act] I tried to remain } \\
\text { calm }\end{array}$ \\
\hline Acceptance & $\begin{array}{l}\text { I simple accept that life it is } \\
\text { like this }\end{array}$ \\
\hline $\begin{array}{l}\text { Social support (emo- } \\
\text { tional) }\end{array}$ & $\begin{array}{l}\text { I searched for help near my co- } \\
\text { lleagues, friends and family }\end{array}$ \\
\hline $\begin{array}{l}\text { Positive reinterpretation } \\
\text { and growth }\end{array}$ & $\begin{array}{l}\text { I thought about the way I was } \\
\text { educated by my parents, in my } \\
\text { military career and how I like } \\
\text { the uniform I have worn during } \\
\text { these past years }\end{array}$ \\
\hline $\begin{array}{l}\text { Focusing on and venting } \\
\text { of emotions }\end{array}$ & $\begin{array}{l}\text { [I didn't do] nothing, I heard and } \\
\text { cried. It was useful to relieve the } \\
\text { tension }\end{array}$ \\
\hline Mental disengagement & $\begin{array}{l}\text { I tried to forget the problems, } \\
\text { finding motivation in the things } \\
\text { I most liked doing and that ma- } \\
\text { de me feel good }\end{array}$ \\
\hline Denial & $\begin{array}{l}\text { I tried not to think I was away } \\
\text { [from my family] }\end{array}$ \\
\hline
\end{tabular}

Regarding the usual sources of stress in the profession, it should be mentioned that the participants had at least one year of professional experience, being capable of answering this question. More specifically, 47 were in the early-career (54\%), 25 in the mid-career $(28.7 \%)$ and 15 at the late-career (17.3\%) (eight participants did not provide information about this topic). Results showed that the intrinsic factors to the job were the biggest cause of distress (55.5\% of the total codes) (table 2). In this category, the two main stress issues were the risks and dangers to the military and/or to the other persons and the work schedule, shift work, and working on the weekend. The second category referred to relationships at work, specifically to the rapport with the commands/superior officer. The roles in the organization, identified as the responsibility and functions, represented the third stress domain. The organizational structure and climate obtained similar scores, pointing out the bureaucracy as one of the main issues that triggered more problems in the military work. The home-work interface presented low scores.

Table 2

Usual Sources of Stress in the Professional Activity

\begin{tabular}{|c|c|c|}
\hline Categories & $n$ & $\%$ \\
\hline Intrinsic to the job & (101) & (55.5) \\
\hline $\begin{array}{l}\text { Risks and dangers to the military and/or to } \\
\text { other persons }\end{array}$ & 28 & 15.4 \\
\hline $\begin{array}{l}\text { Work schedules, shift work, and working in } \\
\text { the weekend }\end{array}$ & 25 & 13.8 \\
\hline $\begin{array}{l}\text { Lack of resources and poor working condi- } \\
\text { tions }\end{array}$ & 18 & 9.9 \\
\hline Excess of working hours & 17 & 9.3 \\
\hline Work overload & 13 & 7.1 \\
\hline Relationships at work & (41) & (22.5) \\
\hline $\begin{array}{l}\text { Relationship with the commands/superior } \\
\text { officer }\end{array}$ & 26 & 14.3 \\
\hline Relationship with citizens and community & 12 & 6.6 \\
\hline Relationship with colleagues & 3 & 1.6 \\
\hline Roles in the organization & (18) & (9.9) \\
\hline Responsibility and functions & 17 & 9.3 \\
\hline Role conflict & 1 & 0.6 \\
\hline Organizational structure and climate & (17) & (9.3) \\
\hline $\begin{array}{l}\text { Bureaucracy, discipline procedures, and } \\
\text { legal aspects }\end{array}$ & 13 & 7.1 \\
\hline Lack of instruction and training & 4 & 2.2 \\
\hline Home-work interface & (5) & (2.8) \\
\hline $\begin{array}{l}\text { Working problems (that reflect in the indi- } \\
\text { vidual) }\end{array}$ & 3 & 1.6 \\
\hline Personal problems (that reflect in the work) & 2 & 1.2 \\
\hline Total valid codes & 182 & \\
\hline
\end{tabular}

The consequences of the usual sources of stress were more prevalent at the individual level, with $90.1 \%$ of the meaning units (table 3 ). In this case, negative effects on the relationships with significant others were reported (e.g., problems with their partner, less proximity with their children, less support to their family, etc.), followed by psychological problems (e.g., nervousness, lack of concentration, irritability, low self-confidence, etc.), and physical and health problems (e.g., hypertension, 
loss or gain of weight, stomach ache, tiredness, etc.). At this level, it was necessary to create the category of "consequences to the family", besides two other domains proposed by Cooper et al. (2001) (psychological and physical problems). In fact, the data analysis showed the evident dominance of this domain, making more sense as an "independent" category that has a substantial effect on the military police officers` life. The second domain, organizational consequences, included $9.9 \%$ of codes, observed on the reduced work and efficiency (e.g., more inefficiency and mistakes committed, etc.), poor relationships at work (e.g., conflicts with colleagues, poor work environment, etc.), and in the low commitment with the organization (indifference towards the job, poor motivation and disinterest to the mission, etc.).

Table 3

Consequences of the Usual Sources of Stress

\begin{tabular}{lcc}
\hline \multicolumn{1}{c}{ Categories } & $n$ & $\%$ \\
\hline Individual symptoms & $\mathbf{( 1 3 8 )}$ & $\mathbf{( 9 0 . 1 )}$ \\
Problems with significant others (e.g., & & \\
family) & 52 & 33.9 \\
Psychological problems & 48 & 31.4 \\
Physical and health problems & 38 & 24.8 \\
& & \\
Organizational symptoms & $\mathbf{( 1 5 )}$ & $\mathbf{( 9 . 9 )}$ \\
Reduced work performance and efficiency & 7 & 4.6 \\
Poor relationships at work & 5 & 3.3 \\
Low commitment & 3 & 2.0 \\
& & \\
Total of valid codes & $\mathbf{1 5 3}$ & \\
& &
\end{tabular}

The description of the main source of stress in the whole career allowed us to verify that the factors intrinsic to the job (30.7\%) and the relationships at work (24\%) were assumed to be the main areas of pressure and distress (table 4). In addition to the usual professional sources of stress, there were also the risks and dangers to the military and/ or to other persons and the relationships with the commands/superior officer that represented the largest causes of problems. On the other hand, the roles in the organization $(16 \%)$, the home-work interface $(13.3 \%)$, and the organizational structure and climate (12\%) assumed lower scores. Presenting almost residual percentages, we could observe aspects relative to the career development (4\%).

Table 4

Main Sources of Stress for the Whole Career

\begin{tabular}{|c|c|c|}
\hline Categories & $n$ & $\%$ \\
\hline Intrinsic to the job & (23) & (30.7) \\
\hline $\begin{array}{l}\text { Risks and dangers to the military and/or to } \\
\text { other persons }\end{array}$ & 18 & 24.0 \\
\hline $\begin{array}{l}\text { Lack of resources and poor working con- } \\
\text { ditions }\end{array}$ & 2 & 2.8 \\
\hline $\begin{array}{l}\text { Work schedules, shift work, and working } \\
\text { in the weekend }\end{array}$ & 1 & 1.3 \\
\hline Excess of working hours & 1 & 1.3 \\
\hline Work overload & 1 & 1.3 \\
\hline Relationships at work & (18) & (24.0) \\
\hline $\begin{array}{l}\text { Relationship with the commands/superior } \\
\text { officer }\end{array}$ & 14 & 18.7 \\
\hline Relationship with citizens and community & 3 & 4.0 \\
\hline Relationship with colleagues & 1 & 1.3 \\
\hline Roles in the organization & (12) & (16.0) \\
\hline Responsibility and functions & 8 & 10.7 \\
\hline Role ambiguity & 4 & 5.3 \\
\hline Home-work interface & (10) & (13.3) \\
\hline $\begin{array}{l}\text { Working problems (that reflect in the indi- } \\
\text { vidual) }\end{array}$ & 8 & 10.5 \\
\hline Personal problems (that reflect in the work) & 2 & 2.8 \\
\hline Organizational structure and climate & (9) & (12.0) \\
\hline $\begin{array}{l}\text { Bureaucracy, discipline procedures, and } \\
\text { legal aspects }\end{array}$ & 9 & 12.0 \\
\hline Career development & (3) & (4.0) \\
\hline Career progression & 2 & 2.7 \\
\hline Payment & 1 & 1.3 \\
\hline Total of valid codes & 75 & \\
\hline
\end{tabular}

The last question asked about the coping strategies to deal with the main source of stress. Table 5 presents the domain of stress and also the respective coping strategies, giving a better understanding of the situations and factors that caused most distress. It should be noted that we categorized 73 coping strategies that correspond to 75 stress situations 
presented in Table 4. This discrepancy was caused by the fact that we were not able to categorize five coping strategies because some participants preferred not to present the specific situation that caused most stress in the whole career.

Table 5

Coping Strategies to Deal with the Main Source of Stress

\begin{tabular}{|c|c|c|}
\hline Sources of stress & Coping strategies & $n(\%)$ \\
\hline Intrinsic to the job & & $24(32.9)$ \\
\hline \multirow{9}{*}{$\begin{array}{l}\text { Risks and dangers } \\
\text { to the military and/ } \\
\text { or to other persons }\end{array}$} & Problem-focused coping & \\
\hline & Active coping & $7(29.2)$ \\
\hline & Social support (instrumental) & $2(8.1)$ \\
\hline & Planning & $1(4.2)$ \\
\hline & Emotion-focused coping & \\
\hline & Social support (emotional) & $4(16.7)$ \\
\hline & Acceptance & $3(12.5)$ \\
\hline & Mental disengagement & $2(8.1)$ \\
\hline & $\begin{array}{l}\text { Positive reinterpretation } \\
\text { and growth }\end{array}$ & $1(4.2)$ \\
\hline \multirow{3}{*}{$\begin{array}{l}\text { Lack of resources } \\
\text { and poor working } \\
\text { conditions }\end{array}$} & Problem-focused coping & \\
\hline & $\begin{array}{l}\text { Active coping } \\
\text { Emotion-focused coping }\end{array}$ & $1(4.2)$ \\
\hline & Acceptance & $1(4.2)$ \\
\hline \multirow{2}{*}{$\begin{array}{l}\text { Excess of working } \\
\text { hours }\end{array}$} & Problem-focused coping & \\
\hline & Active coping & $1(4.2)$ \\
\hline \multirow[t]{2}{*}{ Work overload } & Problem-focused coping & \\
\hline & Planning & $1(4.2)$ \\
\hline $\begin{array}{c}\text { Relationships at } \\
\text { work }\end{array}$ & & $18(24.7)$ \\
\hline \multirow{6}{*}{$\begin{array}{l}\text { Relationship with } \\
\text { the commands/su- } \\
\text { perior officer }\end{array}$} & Problem-focused coping & \\
\hline & Active coping & $4(22.1)$ \\
\hline & $\begin{array}{l}\text { Social support (instrumental) } \\
\text { Emotion-focused coping }\end{array}$ & $2(11.0)$ \\
\hline & Acceptance & $5(27.7)$ \\
\hline & Social support (emotional) & $1(5.6)$ \\
\hline & $\begin{array}{l}\text { Focusing on and venting of } \\
\text { emotions }\end{array}$ & $1(5.6)$ \\
\hline \multirow{3}{*}{$\begin{array}{l}\text { Relationship with } \\
\text { colleagues }\end{array}$} & Emotion-focused coping & \\
\hline & Social support (emotional) & $1(5.6)$ \\
\hline & Mental disengagement & $1(5.6)$ \\
\hline \multirow{4}{*}{$\begin{array}{l}\text { Relationship with } \\
\text { citizens and com- } \\
\text { munity }\end{array}$} & Problem-focused coping & \\
\hline & Active coping & $1(5.6)$ \\
\hline & $\begin{array}{l}\text { Planning } \\
\text { Emotion-focused coping }\end{array}$ & $1(5.6)$ \\
\hline & Acceptance & $1(5.6)$ \\
\hline
\end{tabular}

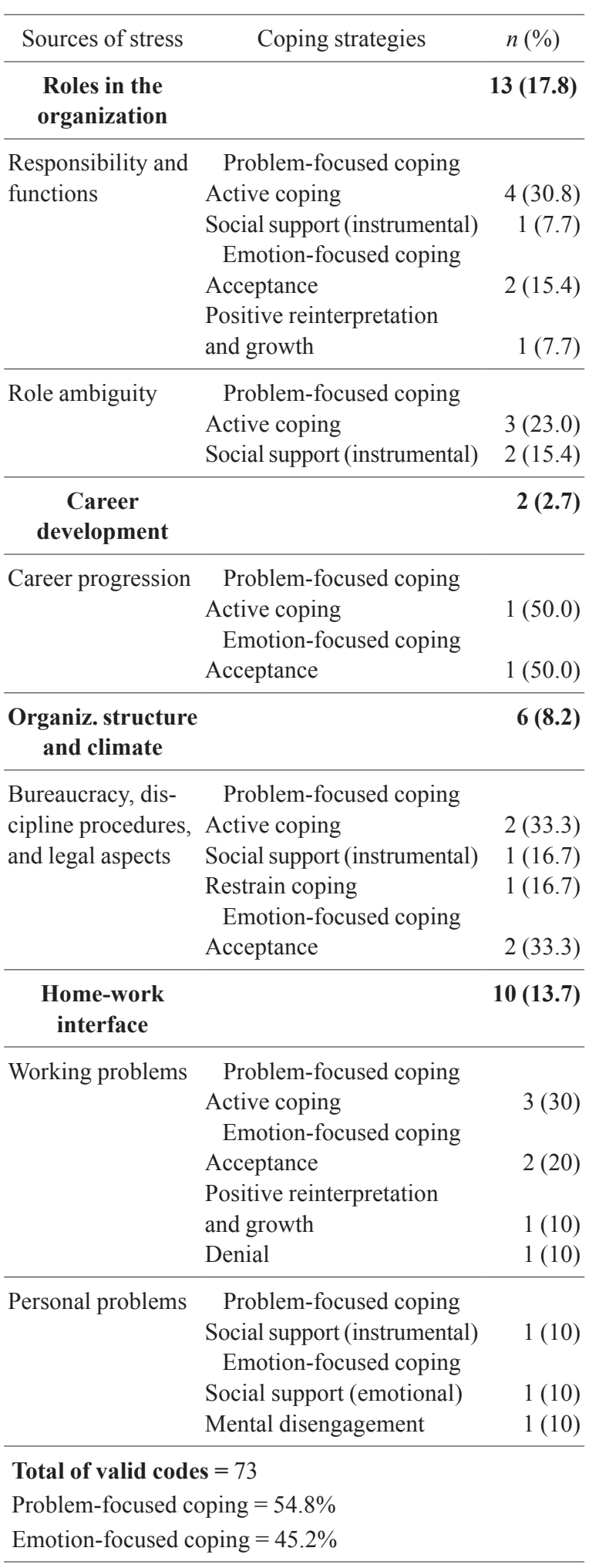

In this way, table 5 presents the sources of stress and the specific coping strategies used to deal with 
each one. For example, active confrontation was applied in seven situations where the military police officers were exposed to a dangerous event to themselves and/or to others. This scheme of data presentation followed the guidelines of Oakland and Ostell (1996), once they affirmed that the comprehension of "efficiency" or "inefficiency" of each coping skill can only be understood when it is describes the context or the specific situation that triggers each coping strategy used by the person. In fact, depending on the person and/or the situation, the same coping strategy can be applied by different people with distinct outcomes for the final adaptation to stress events.

Following the guidelines in coping literature (Carver \& Scheier, 1994; Schnider, Elhai, \& Gray, 2007), it was found a significant diversity of coping strategies, distributed by problem-focused coping (active coping, social/instrumental support, planning and restraint coping), emotion-focused coping (acceptance, social/emotional support, positive reinterpretation and growth, focusing on and venting of emotions), and avoidant coping (mental disengagement and denial). In general, there were a similar distribution between the actions to solve the problems (54.8\%) and the ones used to control the emotional distress $(45.2 \%)$. One of the main aspects that results from this analysis was that for all of the six main domains of stress, there was a substantial diversity of coping strategies. Considering the example of risks and dangers to the military and/or other persons, it was observed twenty different possibilities of dealing with this stressful event. In a more detailed analysis, active coping obtained higher frequencies of use (37\%), followed by instrumental support (12.3\%), planning (4.1\%), and restraint coping (1.4\%). In the group of emotion-focused coping, it was found a more balanced dispersion of the categories, giving relevance to acceptance of the situation that was the strategy most used by military police officers $(23.3 \%)$. The other coping strategies were: emotional support $(9.5 \%)$, mental disengagement $(5.5 \%)$, positive reinterpretation and growth (4.1\%), denial (1.4\%), and focusing on and venting of emotions (1.4\%).

\section{Discussion}

The role of the police force in the occidental societies has suffered a significant transformation, reflecting the economic, social, and technological changes in the global communities, as well as the implementation of democratic political models which tend to defend the individual rights of citizens (Deschamps, Paganon-Badinier, Marchand, $\&$ Merle, 2003). These changes turn the police job even more complex and demanding, making the understanding of how these professionals adapt to their professional stressors more relevant. This study addressed this subject, observing the frequency of stress and analysing the sources of stress and psychological factors that help these professionals cope with the main demands of their profession.

Beginning with the global level of stress, the majority of the participants reported significant to high levels of pressure (54\%). Comparing this result with other studies where it was also applied a measure of general stress level, the percentage of $54 \%$ is near the values obtained by Maslach-Pines and Keinan (2006) with Israeli border police officers $(52 \%)$ and it is above the results obtained by Deschamps et al. (2003) with French police officers $(33 \%)$. These values bring out the importance and the need for a better understanding of the occupational stress experience in this working class, which was one of the main goals of this study.

Concerning the usual sources of stress, factors intrinsic to the job and relationships at work were the main stressors of military police officers. Specifically, the risks and dangers of the job (most stressing domain of all), the relationships with the commands, and the work schedule were the issues that most pressure the military police officers. Some authors also conclude that the relationships with the management represent the most common source of stress among the police officers that tend 
to also trigger work dissatisfaction and psychological distress (Brough, 2004; Burke \& Mikkelsen, 2006). Some studies have also demonstrated that the lack of administrative support and opportunities to participate in decision-making are often reported as the main sources of stress when they are compared with violent and dangerous situations in the daily job routine (e.g., Alexander, 1999; Brown \& Campbell, 1994).

The work schedule, which includes working by shifts and on the weekends, emerged also as an important category in the usual sources of stress (13.8\% of meaning units), being relevant to question the effects that this may have on the professional efficacy and personal well-being of military police officers. One of the studies where this effect was demonstrated took place in Italy with clerical police officers and traffic police (Pancheri et al., 2002). They found that at the end of the shift the traffic controllers had increased scores on the depressive scale.

In a second group of stressors, presenting less meaning units than the previous categories, it was found the lack of resources and poor working conditions, the excess of working hours, the work overload, and the relationship with citizens and the community also represented sources of stress for the military police officers. These types of complaints have also been described in other studies. As an example, Biggam, Power, MacDonald, Carcary and Moodie (1997b) concluded that staff shortages (mentioned by $81 \%$ of police officers), inadequate resources $(78 \%)$, time pressure $(74 \%)$, and work overload (71\%) represented some of the most stressful problems for these professionals.

The analysis of the usual sources of professional pressure corroborates the results found in the main sources of stress. In fact, the risks and dangers to the military and/or to other persons and the relationships with the command/superior officer represented the issues that promote the greatest distress in the whole professional career. Some studies that have analysed acute (or critical) sour- ces of stress partially confirm these indications, specifically the impact of danger reported by the police officers on their physical well-being and the well-being of others. As an example, Toch (2002) affirmed that the fear that the police officers felt of getting wounded or dying on duty represents the acute stressor that most concern these professionals. Also, the stress related to risks for others (e.g., colleagues and civilians) is also reported in literature (Violanti \& Patton, 1999). This aspect is even more important when we think about the possible consequences to police officers. In fact, Vanheule et al. (2008), in a study with security guards, revealed that the experience of a critical incident (e.g., serious confrontation that is sufficiently disturbing to overwhelm or threaten the individual's usual way of coping) occurs very frequently (41.1\% experienced a work-related critical incident) and can promote post-traumatic stress complaints and contributes significantly to the explanation of burnout.

In terms of the consequences of the usual stress, four aspects should be mentioned. First, the great majority of the negative effects were felt at an individual level (90.1\% of meaning units). In this case, problems with significant others (e.g., conflicts with their partner, less proximity to their children, less support to the family, etc.) were the most prevalent (33.9\%), leading us to believe that the family issues are one of the strongest domains impaired by the professional activity. Research confirms this impact of work stress on family, such as divorce rates, marital discord, disruption of family life, child-rearing problems, sexual promiscuity, infidelity, loss of non-police friends, etc. (Terry, 1981). It is interesting to verify that one of the main complaints assumed by the military police officers in our study was the impossibility of planning moments of leisure and personal contact on a regular basis with their companion and children, leading to tension situations between all of them. Second, psychological problems (e.g., nervousness, lack of concentration, irritability, low self-confidence, 
etc.) were the second category most referred by the military police officers (31.4\%). These effects have also been presented in other studies, specifically the difficulty to concentrate, increase aggressiveness and violence, and alcohol abuse and drugs (see Davey, Obst, \& Sheehan, 2001). Third, physical effects was also very referred by the participants (24.8\%). In this case, the problems described by the military police officers (e.g., hypertension, loss or gain of weight, stomach ache, tiredness, etc.) are in consonance with the symptoms presented in other studies (Perrier, 1984). Fourth, the organizational consequences of usual stress $(9.9 \%$ of the meaning units) were observed in terms of lower professional performance (e.g., increase number of errors committed, etc.), poor relationships at work (e.g., conflicts with colleagues, poor working environment, etc.), and low organizational commitment (e.g., indifference to the job, low motivation and disinterest towards the mission, etc.). Some of these organizational effects (e.g., decrease of efficiency, more errors committed, low motivation and indifference) have also been found in other studies that focused their attention on the negative consequences of occupational stress on the culture and efficiency of police organizations (Brown \& Campbell, 1994; Cooper, Kirkcaldy, \& Brown, 1994).

In the last question (coping strategies), one of the most significant findings was the resemblance between problem-focused coping strategies $(54.8 \%)$ and emotion-focused coping strategies (45.2\%). Curiously, this balanced distribution occurs between the two main sources of stress in the professional career: the relationship with the command/superior officer (six cases of problem-focused solutions and seven cases of emotion-focused coping strategies) and the risks and dangers relative to the job (ten cases in each coping domain). The slight preference of using problem-focused strategies when compared to emotion-based strategies has been described in other studies (Biggam et al., 1997a), but the most relevant aspect in our case was the fact that both coping domains are used to deal with the same stressful event in the whole career.

\section{Concluding remarks}

One of the main conclusions of this study is the fact that intrinsic factors to the job (e.g., the nature of police work) represent a strong domain of distress at work. An example of this, are the reports about risks and dangers to the military police officers' integrity. This aspect may lead us to think about the feelings of personal security and well-being that exists in this working class.

Another important factor related to the own police organization. In this case, the work schedule and the relationships with the command/superior officer were the most stressful domains. In the first case, there seemed to be a low perception of control and autonomy in the work schedule definition. This situation produces multiple effects, especially in the relationship with their families. In the second case, the relationships with the command/ superior officers represents one of the main usual sources of stress, and this aspect is well confirmed by other studies (for a review, see Biggam et al., 1997b). However, the most disconcerting aspect is the fact that this domain is also the largest source of distress throughout the entire career of military police officers. Knowing this, we may question if the problems with their superiors officers are a normal condition of the working relationships or represent a highly unwanted and undesirable aspect, due to the importance of trust and support in this professional class. By the other hand, the military structure that characterizes the Portuguese Republican National Guard can indeed explain this aspect, being strongly reinforced the principle of discipline and the respect for authority.

When it comes to the consequences of stress, the principal finding is the fact that working problems are especially felt at the individual and family levels. Even though this study is about the military police officers`self-perceptions (and because 
of that there is no objective indication that these effects are real), we may ask about the practical implication of this situation to the prevention and treatment of occupational stress. By other words, what resources could be mobilized to help these professionals when the effects are mainly experienced at individual and family levels? What kind of training has the police officers to deal with these problems? Are the professionals aware and prepared to face these consequences?

Concerning the strategies to deal with stress, we must underline the high percentage of emotion-focused coping. In this case, the problems with their superior officers seem to trigger problem-focused coping strategies and emotion-focused strategies, suggesting that the military police officers sometimes present and defend their own point of view (problem resolution) and other times they seem to bend their will to the power of their superior officers (emotion-focused). What effects this will have on the culture of the organization and on the professional commitment is a question that should be made. From a conceptual point of view, the fact that police officers could respond very differently to similar stress situations, confirms the importance of analysing cognitive appraisals, namely the way they interpret the situation (primary appraisal) and the way they evaluate their coping resources to deal with the problem (secondary appraisal) (Lazarus, 1991). Also, the perception of control that military police officers perceive over these sources of stress can help explain their coping strategies: the ones that feel more control over the stressors may tend to use problem-focused coping strategies while the ones that feel less control over the stressors may tend to use emotion-focused coping strategies (Karasek, 1979).

Despite the significant amount of information and indications gathered in this study, some limitations should be mentioned. The sample is not a representative one of all the military police officers (but corresponds to $37 \%$ of the military police officers that were working in the evaluated Post
Commanders), being also somewhat homogeneous in their demographic characteristics. Also, it was not established in each question of the evaluation protocol a minimum number of answers, being possible that not all participants have expressed everything they thought.

Future research should implement longitudinal and more specific studies, striving to capture the whole subjective experience of these professionals, examining the way they perceive and interpret their work activity (e.g., focus group, in-depth interviews, etc.). Besides, the studies should analyse the importance of demographic and personal variables on the stress experience, because the sample we have collected did not allow us to make this type of analysis (e.g., differences between men and women).

These efforts may help minimize the association between stress and psychological and health problems, making the police officers`experience more rewarding and motivating.

\section{References}

Abdollahi, A. K. (2002). Understanding police stress research. Journal of Forensic Psychology Practice, 2(2), 1-24.

Alexander, C. (1999). Police psychological burnout and trauma. In J. M. Violanti \& D. Paton (Eds.), Police trauma: Psychological aftermath of civilian combat (pp. 54-64). Springfield IL: Charles C. Thomas.

Alexander, D. A., \& Klein, S. (2001). Ambulance personnel and critical incidents: Impact of accident and emergency work on mental health and emotional well-being. British Journal of Psychiatry, 178, 76-81.

Alexander, D. A., \& Walker, L. G. (1996). The perceived impact of police work on police officers' spouses and families. Stress Medicine, 12, 239-246.

Biggam, F. H., Power, K. G., \& MacDonald, R. R. (1997a). Coping with the occupational stressors 
of police work: A study of Scottish officers. Stress Medicine, 13, 109-115.

Biggam, F. H., Power, K. G., MacDonald, R. R., Carcary, W. B., \& Moodie, E. (1997b). Self-perceived occupational stress distress in a Scottish police force. Work \& Stress, 11, 118-133.

Bodgan, R. C., \& Biklen, S. N. (2006). Qualitative research for education: An introduction to theory and methods (5th ed.). Toronto: Allyn \& Bacon.

Brough, P. (2002). Female police officers' work experiences, job satisfaction and psychological well-being. Psychology of Women Section Review, 4, 3-15.

Brough, P. (2004). Comparing the influence of traumatic and organizational stressors on the psychological health of police, fire, and ambulance officers. International Journal of Stress Management, 11, 227-244.

Brown, J. M., \& Campbell, E. A. (1994). Stress and policing: Sources and strategies. New York: Wiley.

Burke, R. J., \& Mikkelsen, A. (2006). Examining the career plateau among police officers. Policing: An International Journal of Police Strategies \& Management, 29(4), 691-703.

Campbell, D. J., \& Nobel, O. (2009). Occupational stressors in military service: A review and framework. Military Psychology, 21, S47-S67.

Carver, C. S., \& Scheier, M. F. (1994). Situational coping and coping dispositions in a stressful transaction. Journal of Personality and Social Psychology, 66, 184-195.

Carver, C. S., Scheier, M. F, \& Weintraub, J. K. (1989). Assessing coping strategies: A theoretically based approach. Journal of Personality and Social Psychology, 56, 267-283.

Cooper, C. L., Dewe, P. J., \& O' Driscoll, M. P. (2001). Organizational stress: A review and critique of theory, research, and applications. London: Sage.

Cooper, C. L., Kirkcaldy, B. D., \& Brown, J. (1994). A model of job stress and physical health: The role of individual differences. Personality and Individual Differences, 16, 653-655.

Coyne, J. C., \& Racioppo, M. W. (2000). Never the twain shall meet? Closing the gap between coping research and clinical intervention research. American Psychologist, 55, 655-664.

Davey, J. D., Obst, P. L., \& Sheehan, M. C. (2001). It goes with the job: Officers' insights into stress and the culture of alcohol consumption within the policing occupation. Drugs: Education, Prevention and Policy, 8, 141-149.

De Boer, E. M., Bakker, A. B., Syroit, J. E., \& Schaufeli, W. B. (2002). Unfairness at work as a predictor of absenteeism. Journal of Organizational Behavior, 23, 181-197.

Deschamps, F., Paganon-Badinier, I., Marchand, A. C., \& Merle, C. (2003). Sources and assessment of occupational stress in the police. Journal of Occupational Health, 45, 358-364.

Dewe, P. J., O’Driscoll, M. P., \& Cooper, C. L. (2010). Coping with work stress: A review and critique. Chichester, UK: Wiley.

Folkman, S. (2008). The case for positive emotions in the stress process. Anxiety, Stress, \& Coping, 21(1), 3-14.

Folkman, S., \& Lazarus, R. S. (1980). An analysis of coping in a middle-aged community sample. Journal of Health and Social Behavior, 21, 219-239.

Folkman, S., \& Lazarus, R. S. (1988). Ways of coping questionnaire: Sampler set, manual, test booklet, scoring key. Redwood City, California: Consulting Psychologists Press.

Folkman, S., Lazarus, R. S., Dunkel-Schetter, C., De Longis, A., \& Gruen, R. J. (1986). Dynamics of a stressful encounter: Cognitive appraisal, coping and encounter outcomes. Journal of Personality and Social, 50, 992-1003.

Gomes, A. R. (2014). Positive human functioning in stress situations: An interactive proposal. In A. R. Gomes, R. Resende, \& A. Albuquerque (eds.), Positive human functioning from a multidimensional perspective: Promoting stress 
adaptation (Vol. 1, pp. 165-194). New York: Nova Science.

Hart, P. M., \& Cotton, P. (2003). Conventional wisdom is often misleading: Police stress within an organisational health framework. In M. F. Dollard, A. H. Winefield, \& H. R. Winefield (Eds.), Occupational stress in the service professions (pp. 103-141). London: Taylor \& Francis.

Holsti, O. (1969). Content analysis for the social sciences and humanities. Don Mills: Addison-Wesley Publishing Company.

Karasek, R. A. (1979). Job demands, job decision latitude, and mental strain: Implications for job redesign. Administrative Science Quarterly, 24(2), 285-308.

Kop, N., Euwema, M. C., \& Schaufeli, W. B. (1999). Burnout, job stress and violent behaviour among Dutch police officers. Work \& Stress, 13, 326340.

Kyriacou, C. (2000). Stress-busting for teachers. Cheltenham: Stanley Thornes.

Lazarus, R. S. (1991). Emotion and adaptation. New York: Oxford University Press.

Lazarus, R. S. (1999). Stress and emotion: A new synthesis. New York: Springer.

Lazarus, R. S. (2000). Cognitive motivational relational theory of emotion. In Y. L. Hanin (Ed.), Emotions in sport (pp. 39-64). Champaign, IL: Human Kinetics.

Lazarus, R. S., \& Folkman, S. (1984). Stress, appraisal, and coping. New York: Springer.

LeBlanc, V. R., Regehr, C., Jelley, R. B., \& Barath, I. (2008). The relationship between coping styles, performance, and responses to stressful scenarios in police recruits. International Journal of Stress Management, 15, 76-93.

Lincoln, Y., \& Guba, E. (1985). Naturalistic inquiry. Beverly Hills, CA: Sage.

Maslach-Pines, A., \& Keinan, G. (2006). Stress and burnout in Israeli border police. International Journal of Stress Management, 13, 519-540.
Oakland, S., \& Ostell, A. (1996). Measuring coping: A review and critique. Human Relations, 49, 133-155.

Pancheri, P., Martini, A., Tarsitani, L., Rosati, M. V., Biondi, M., \& Tomei, F. (2002). Assessment of subjective stress in the municipal police force of the city of Rome. Stress and Health, 18, 127-132.

Patton, M. Q. (1990). Qualitative evaluation and research methods (2nd ed.). Newbury Park, CA: Sage.

Payne, R. L., \& Cooper, C. L. (2004). Emotions at work: Theory, research and applications for management. Chichester, UK: Wiley.

Perrier, D. C. (1984). Police stress: The hidden foe. Canadian Police College Journal, 8, 15-26.

Riffe, D., Lacy, S., \& Fico, F. (1998). Analyzing media messages: Quantitative content analysis. New Jersey: Lawrence Erlbaum Associates, Inc.

Rourke, L., Anderson, T., Garrison, D. R., \& Archer, W. (2001). Methodological issues in the content analysis of computer conference transcripts. International Journal of Artificial Intelligence in Education, 12, 8-22.

Schaufeli, W. B., \& Enzmann, D. (1998). The burnout companion to study and practice: A critical analysis. London: Taylor \& Francis.

Scheier, M. F., \& Carver, C. S. (1988). A model of behavioural self-regulation: Translating intention into action. In L. Berkowitz (Ed.), Advances in experimental social psychology (Vol. 21, pp. 303-346). New York: Academic Press.

Schnider, K. R., Elhai, J. D., \& Gray, M. J. (2007). Coping style use predicts posttraumatic stress and complicated grief symptom severity among college students reporting a traumatic loss. Journal of Counseling Psychology, 54, 344-350.

Terry, W. (1981). Police stress: The empirical evidence. Journal of Police Science and Administration, 9, 61-75.

Tesch, R. (1990). Qualitative research analysis types and software tools. New York: Falmer Press. 
Toch, H. (2002). Stress in policing. Washington, DC: American Psychological Association.

Vanheule, S., Declercq, F., Meganck, R., \& Desmet, M. (2008). Burnout, critical incidents and social support in security guards. Stress and Health, 24, 137-141.

Violanti, J. M., Andrew, M. E., Burchfiel, C. M., Dorn, J., Hartley, T., \& Miller, D. B. (2006). Posttraumatic stress symptoms and subclini- cal cardiovascular disease in police officers. International Journal of Stress Management, 13, 541-554.

Violanti, J. M., \& Paton, D. (1999). Police trauma: Psychological aftermath of civilian combat. Springfield, IL: Charles C. Thomas.

Weber, R. P. (1985). Basic content analysis. Beveryl Hills, CA: Sage. 
